УДК 339.944.2::378

JEL classification: F19, F60, I21

Шишолін А.П.

начальник відділу зовнішньоекономічної діяльності ORCID ID: 0000-0003-4178-3884

Національний технічний університет України

«Київький політехнічний інститут імені Ігоря Сікорського»

\title{
ЗОВНІШНЬОЕКОНОМІЧНА ДІЯЛЬНІСТЬ ЯК РЕСУРС ІНТЕРНАЦІОНАЛІЗАЦІЇ УНІВЕРСИТЕТУ
}

\author{
ВНЕШНЕЭКОНОМИЧЕСКАЯ ДЕЯТЕЛЬНОСТЬ КАК РЕСУРС \\ ИНТЕРНАЦИОНАЛИЗАЦИИ УНИВЕРСИТЕТА
}

\section{FOREIGN ECONOMIC ACTIVITY AS A SOURCE FOR AN INTERNATIONALIZATION OF THE UNIVERSITY}

У роботі запропоновано підхід до зовнішньоекономічної діяльності університету як ключового економічного ресурсу інтерначіоналізачії ВНЗ. Проведено огляд світового досвіду здійснення університетами зовнішньоекономічної діяльності в частині експорту освітніх послуг та послуг в сфері науково-технічної діяльності через призму Генеральної угоди з торгівлі послугами. Здійснено детальний аналіз реалізації механізмів, зазначених у Генеральній угоді з торгівлі послугами. Автором зроблена спроба адаптувати вищевказані міжнародні механізми до існуючого вітчизняного законодавства в частині дозволених платних послуг, які можуть надаватись вищими навчальними закладами в сфері освіти, науки, техніки $i$ інноватики. У статті окремо виділено адміністративний супровід зовнішньоекономічної діяльності. Показано зв'язок надходжень від експортної складової зовнішньоекономічної діяльності з імпортом освітніх послуг, що безпосередньо впливає на розвиток інтернаціоналізаџіï університету як прочесу інтегращії міжнародних елементів в освітні, наукові та адміністративні функиії вищого навчального закладу.

Ключові слова: зовнішньоекономічна діяльність, трансфер знань, університет, інтернаціоналізація

В работе предложен подход к внешнеэкономической деятельности университета как ключевому экономическому ресурсу интернационализации ВУЗа. Проведен обзор мирового опыта осуществления университетами внешнеэкономической деятельности в части экспорта образовательных услуг и услуг в сфере научно-технической деятельности через призму Генерального соглашения по торговле услугами. Осуществлен подробный анализ реализации механизмов, указанных в Генеральном соглашении по торговле услугами. Автором предпринята попытка адаптировать вышеуказанные международные механизмы к существующему отечественному законодательству в части разрешенных платных услуг, которые могут предоставляться высшими учебными заведениями в сфере образования, науки, техники $u$ инноватики. $B$ статье отдельно выделено административное сопровождение внешнеэкономической деятельности. Показана связь поступлений от экспортной составляющей внешнеэкономической деятельности с импортом образовательных услуг, что непосредственно влияет на развитие интернационализации университета как процесса интеграџии международных элементов в образовательные, научные и административные функиии высшего учебного заведения. 
Ключевые слова: внешнеэкономическая деятельность, трансфер знаний, университет, интернационализация

In this paper, an approach to the foreign economic activity of the university as a key economic resource for the internationalization of the university was suggested. A review of international experience of implementation by universities of foreign economic activity in terms of export of educational services and services in the field of scientific and technical activities was conducted through the prism of the General agreement on trade in services. Mechanisms of the General agreement on trade in services were described in details. The author carried out the adaptation of the above-mentioned international mechanisms to existing domestic legislation in terms of permitted services that may be provided by higher educational institutions in the field of education, science, technology and innovation, administrative support of foreign economic activities was observed. In the article, administrative support for foreign economic activity was singled out separately.The relationship of earnings from foreign trade on the development of the internationalization of the University as the process of integration of international elements into the educational, research and administrative functions of higher education was shown.

Keywords: foreign economic activity, knowledge transfer, university, internationalization

Вступ. Однією 3 основних тенденцій сучасного розвитку освіти є іï комерціалізація, що виявляється у формуванні міжнародного ринку освітніх послуг з окремою статтею експорту - експорту освітніх послуг іноземним студентам. У такому контексті актуалізується зовнішньоекономічна складова діяльності університетів.

Процеси глобалізації та інтернаціоналізації зумовлюють необхідність самовизначення окремих університетів, знаходження своєї ніші в глобальному освітньому просторі, відповідного коригування діяльності в якості суб'єкта міжнародного ринку. При цьому робота університету в частині імпортноекспортних операцій підпорядкована тим же принципам i законам, механізмам здійснення зовнішньоекономічної діяльності, що і будь-яких бізнес-компаній.

Разом 3 тим, специфіка університетського «продукту», а також значна соціальна роль університету обумовлюють актуальність та необхідність дослідження зовнішньоекономічної діяльності в контексті функціонування університету. Важливою є адаптація бізнес-підходу до освітніх реалій і потреб суспільства, світових стандартів 3 підсумковим формуванням оптимальної моделі організації зовнішньоекономічної діяльності, яка б дозволила не лише отримати додаткові кошти для утримання університету, але й сконцентрувати їх для сприяння інтернаціоналізації.

Особливої актуальності заявлена проблема набуває для технічних університетів з урахуванням їх ролі в формуванні та розвитку інноваційної економіки і забезпеченні соціально-економічного зростання окремих держав $\mathrm{i}$ регіонів.

Питання трансферу знань, експорту освітніх послуг та трансферу технологій, комерціалізації освіти і науки висвітлені в роботах вітчизняних науковців М.3. Згуровського [1], С.В. Войтко [2], В.В. Дергачьової та їх 
закордонних колег П. Альтбаха, Б. Бірела, Г. Горської та інших. Вказані науковці послідовно опрацювали питання становлення міжнародної системи трансферу знань [3], наявні проблемні аспекти, включаючи міжнародне регулювання торгівлі послугами [4], виявили тенденції розвитку країн [5] та здійснили наукове передбачення розвитку як країни в цілому, так і окремих сфер їі життя [6].

Постановка завдання. Дослідження зовнішньоекономічної діяльності як ключового економічного ресурсу здійснення інтернаціоналізації, досягнення ii цілей та задач у практиці функціонування вітчизняних університетів.

Методологія. Теоретичну базу даного дослідження становлять міжнародні угоди $з$ торгівлі послугами та вітчизняного законодавства 3 питань здійснення зовнішньоекономічної діяльності задля виділення основних механізмів, наукові праці низки вчених-економістів 3 зазначеної проблематики, офіційні звіти та статистичні дані, що відображають сучасні тенденції розвитку ринків освітніх послуг та трансферу технологій. У ході дослідження, використано комплекс наукових методів досліджень, серед яких, абстрактно-логічний (теоретичні узагальнення i формування висновків), статистико-економічний (аналіз сучасного стану освітньої та інноваційної активності вищих навчальних закладів України), порівняння використання механізмів зовнішньоекономічної діяльності для створення ресурсу для розвитку інтернаціоналізації вишу.

Результати дослідження. На думку П. Альтбаха [7] тісно пов'язані і часто використовуються як синоніми терміни глобалізація i інтернаціоналізація вищої освіти відносяться до двох різних явищ. Глобалізація, як правило, посилається на широкі економічні, технологічні і наукові напрямки, які безпосередньо впливають на вищу освіту і в значній мірі неминучі в сучасному світі. Інтернаціоналізація, 3 іншого боку, має більше спільного 3 «конкретної політики i програм, що здійснюються урядами, науковими системами та інститутами, і навіть окремих відомств, щоб мати справу з глобалізацією». Інтернаціоналізація - це процес інтеграції міжнародних, міжкультурних і глобальних елементів в освітні (педагогічні), наукові й адміністративні функції окремо взятої організації [8].

На думку, колишнього першого заступника міністра освіти і науки України (2014-2016 рр.) I. Совсун серед переваг інтернаціоналізації можна виділити три аспекти. Перший - це формування зрозумілої для міжнародної спільноти системи вищої освіти, що досягатиметься шляхом інтеграції 3 європейським простором вищої освіти і дослідницьким простором. Другий аспект - забезпечення конкурентоздатності українських вищих навчальних закладів, що можна досягти підтримуючи міжнародне співробітництво університетів, їх участь у міжнародних проектах та програмах, підвищення якості вищої освіти в середині кожного університету. Третій - це посилення 
потенціалу вищих навчальних закладів, підготовка їх до активної участі у міжнародних проектах [9].

Інтернаціоналізація ВН3 у загальному вигляді здійснюється за наступними напрямами:

- освітній процес;

- наукова діяльність;

- інформаційно-рекламна діяльність;

- фінансування;

- в'язки з випускниками;

- міжнародна співпраця;

- експорт освітніх послуг.

У сучасних умовах університет - це де факто підприємство (не в розумінні господарського та цивільного законодавства України, але з точки зору суб' єкта ринку), яке здійснює свою роботу відповідно до законів ринку. Головною функцією університету $є$ надання освітніх послуг. Залежно від рівня затребуваності, вони можуть реалізовуватись як в Україні, так і поза іiі межами. Інтернаціоналізація освіти, при якій створюється додана вартість $€$ експортом освітніх послуг. У сучасній ситуації спрямованості університету до автономії та фінансової незалежності він має постійно розширювати власні кордони, в тому числі у питанні диверсифікації джерел грошових надходжень. Значна роль у цьому питанні відводиться зовнішньоекономічній діяльності як одному з важливих напрямів сучасного розвитку університету.

Зовнішньоекономічна діяльність - діяльність суб'єктів господарювання України та іноземних суб'єктів господарської діяльності, побудована на взаємовідносинах між ними, що має місце як на території України, так і за їі межами [10]. Для університетів внутрішній зміст зовнішньоекономічної діяльності складає сукупність заходів з трансферу знань (експорту та імпорту освітніх послуг та результатів науково-технічної діяльності), орієнтованих на світовий ринок, з урахуванням форм і методів роботи на зарубіжних ринках, а також наявних тенденцій.

Фактично, на рівні університету зовнішньоекономічна діяльність - це сфера господарської діяльності, пов'язана 3 міжнародною виробничою i науково-технічною кооперацією, експортом та імпортом продукції та послуг, в т.ч. - в сфері освіти, а також трансфером технологій, розширенням міжнародного науково-технічного співробітництва у цій сфері [11].

На міжнародному рівні діяльність із трансферу знань у частині експорту-імпорту освітніх послуг врегульовано Генеральною угодою 3 торгівлі послугами, де чітко дано визначення, що торгівля послугами означає поставку послуг [12]: А) 3 території одного члена на територію будь-якого іншого члена; Б) на території одного члена споживачеві послуг будь-якого іншого члена; C) постачальником послуг однієї країни-члена шляхом комерційної присутності на території будь-якого іншого члена; Д) 
постачальником послуг однієї країни-члена шляхом присутності фізичних осіб члена на території будь-якого іншого члена.

Таким чином, адаптуючи наявні механізми постачання послуг до сфери освіти, а саме трансферу знань, доходимо висновку, що постачання послуг може здійснюватися одним з чотирьох основних способів (рис.1):

1) транскордонна поставка - надання послуг з території однієї держави на територію іншої у формі франчайзингу, валідації, розробки спільних програм, дистанційного навчання тощо;

2) споживання за кордоном - отримання послуги поза країною постійного мешкання або реєстрації, тобто - як приклад - це отримання освіти студентами закордоном, проходження стажування викладачами закордоном та інші;

3) комерційна присутність - це такий спосіб постачання послуг, при якому іноземний постачальник «вкорінюється» в країні постачання послуги через створення філіалів, представництв, придбання або заснування компанії на території іншої країни. Англомовна література 3 даної тематики надає узагальнююче найменування цим структурам - branch or offshore campus;

4) переміщення фізичних осіб - це спосіб транскордонного постачання освітніх послуг, коли викладачі або науковці університету однієї країни короткотерміново надають освітні або науково-технічні послуги в університеті іншої країни.

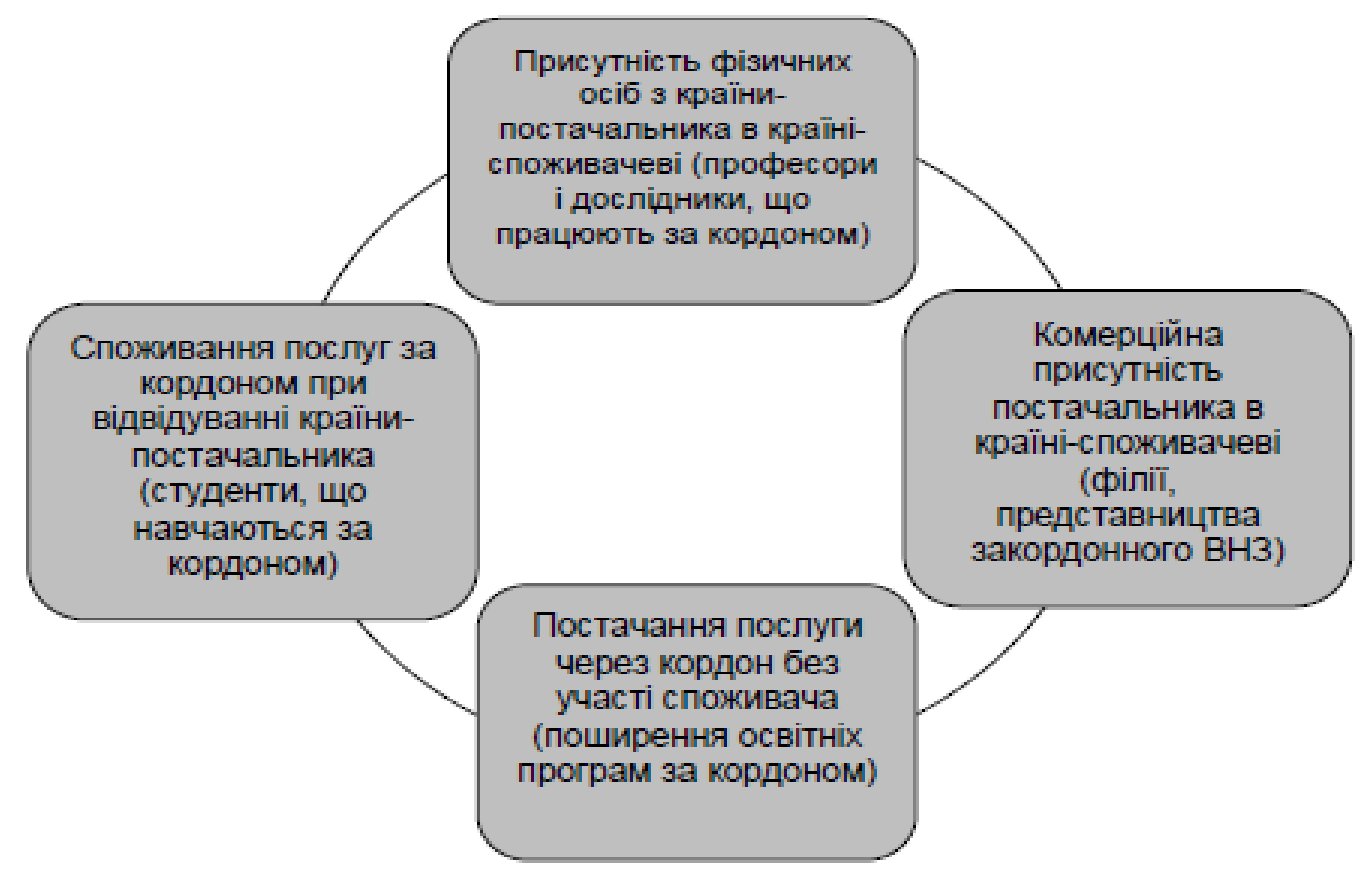

Рис.1. Міжнародний трансфер освітніх послуг

Джерело: систематизовано на підставі [12]

Таким чином, якщо розглянути напрями зовнішньоекономічної діяльності в університеті, які істотно впливають на показники інтернаціоналізації університету, то ними будуть: надання послуг у сфері 
освіти, участь у міжнародних проектах і програмах, залучення іноземних інвестицій, створення спільних міжнародних структур, трансфер освітніх послуг та технологій, супровід проектів 3 благодійної та гуманітарної допомоги, реалізація проектів 3 міжнародної технічної допомоги, інформаційно-аналітичне забезпечення та інші.

Більш узагальнено зовнішньоекономічну діяльність університету можна розділити на три взаємопов'язані групи (рис. 2).

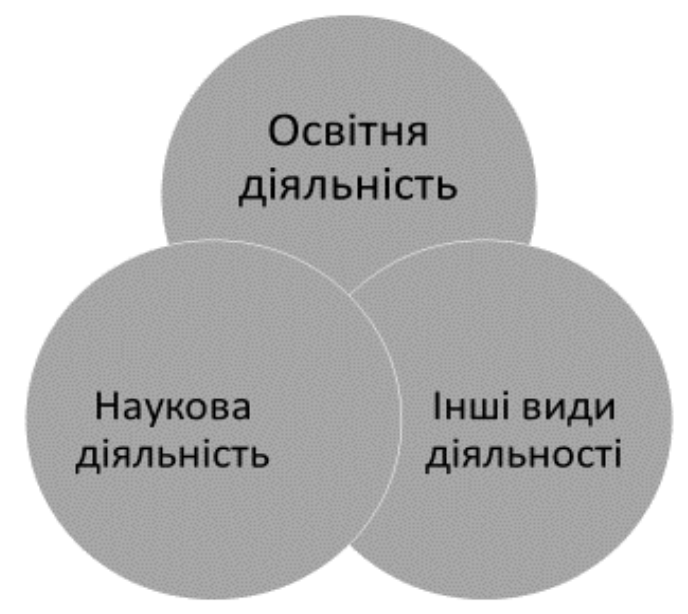

Рис. 2. Складові ЗЕД університету Джерело: побудовано на підставі [11]

Адаптуючи дозволені вітчизняним законодавством види платних послуг, які можуть надаватися вищими навчальними закладами, до особливостей здійснення зовнішньоекономічної діяльності, отримаємо наступне:

1. Зовнішньоекономічна діяльність в сфері освіти:

- навчання і стажування студентів, аспірантів, докторантів 3 числа іноземців та осіб без громадянства;

- друга вища освіта для осіб з числа іноземців та осіб без громадянства;

- підвищення кваліфікації, навчання для здобуття особами 3 числа іноземців та осіб без громадянства післядипломної освіти;

- підготовка до вступу до вищих навчальних закладів та до зовнішнього незалежного оцінювання особами 3 числа іноземців та осіб без громадянства;

- прийом кандидатських іспитів, видання та розповсюдження авторефератів, дисертацій, стенографування під час захисту дисертацій, організація, підготовка до захисту дисертацій на здобуття наукового ступеня кандидата або доктора наук та його проведення для осіб, які навчалися відповідно до договорів, укладених з іноземцями-фізичними особами або іноземними юридичними особами;

- здійснення наукового супроводження осіб з числа іноземців та осіб без громадянства, які підвищують кваліфікацію самостійно, та стажування таких осіб; 
- проведення лекцій та консультацій з питань науки, техніки, права, культури, мистецтва для іноземців як в Україні так і закордоном;

- проведення понад обсяги, встановлені навчальними планами, з видачою або без видачі відповідних документів про освіту курсів, гуртків, факультативів за науковим, технічним, екологічним, гуманітарним напрямами для іноземців;

- складення бібліографічних списків для курсових, дипломних і наукових робіт, каталогів для особистих бібліотек, бібліотек підприємств, установ та організацій, підготовка фактографічних, аналітичних і бібліографічних довідок на замовлення іноземних фізичних та юридичних осіб.

Освітня діяльність, як основна функція університету, в частині інтернаціоналізації повинна стати важливою, власне, найважливішою складовою його зовнішньоекономічної діяльності.

2. Зовнішньоекономічна діяльність в сфері науки, техніки та інноватики:

- проведення науково-дослідних, дослідно-конструкторських, проектноконструкторських, технологічних, пошукових та проектно-пошукових робіт на замовлення іноземних фізичних та юридичних осіб;

- проведення робіт 3 діагностики, стандартизації i сертифікації технологічних процесів, обладнання та матеріалів, метрологічного забезпечення, технічного захисту інформації на замовлення іноземних фізичних та юридичних осіб;

- проведення досліджень щодо розвитку окремих галузей економіки та кон'юнктурних досліджень на замовлення іноземних фізичних та юридичних осіб;

- проведення наукової, науково-технічної, інших видів експертиз в установленому законодавством порядку на замовлення іноземних фізичних та юридичних осіб;

- проектування, розроблення та виготовлення експериментальних зразків $\mathrm{i}$ дослідних партій матеріалів, речовин, приладів, обладнання на замовлення іноземних фізичних та юридичних осіб;

- випробування обладнання, конструкцій, виробів, речовин, матеріалів на замовлення іноземних фізичних та юридичних осіб;

- проведення консультацій з питань наукових досліджень, їх організації та наукового обслуговування на замовлення іноземних фізичних та юридичних осіб;

- впровадження, виробництво і реалізація дослідної, промислової, наукової, науково-технічної, інноваційної продукції, техніки, обладнання, приладів та устаткування, що виготовлені за власними технологіями на замовлення іноземних фізичних та юридичних осіб;

- здійснення операцій, пов'язаних із трансфером (передачею) технологій, що розроблені за рахунок коштів державного бюджету на замовлення іноземних фізичних та юридичних осіб; 
- проведення лабораторних аналізів і досліджень зразків на замовлення іноземних фізичних та юридичних осіб;

- послуги з розроблення науково-технічної документації на замовлення іноземних фізичних та юридичних осіб;

- організація та проведення наукових заходів (з'їздів, семінарів, конференцій тощо) на замовлення іноземних фізичних та юридичних осіб.

- Адміністративний супровід зовнішньоекономічної діяльності:

- проведення експортно-імпортних операцій для навчальних, наукових, господарських потреб та інших потреб університету;

- здійснення міжнародного інвестиційного співробітництва.

Адаптуючи вищенаведене до міжнародної системи регулювання торгівлі послугами можна отримати наступний результат (рис.3):

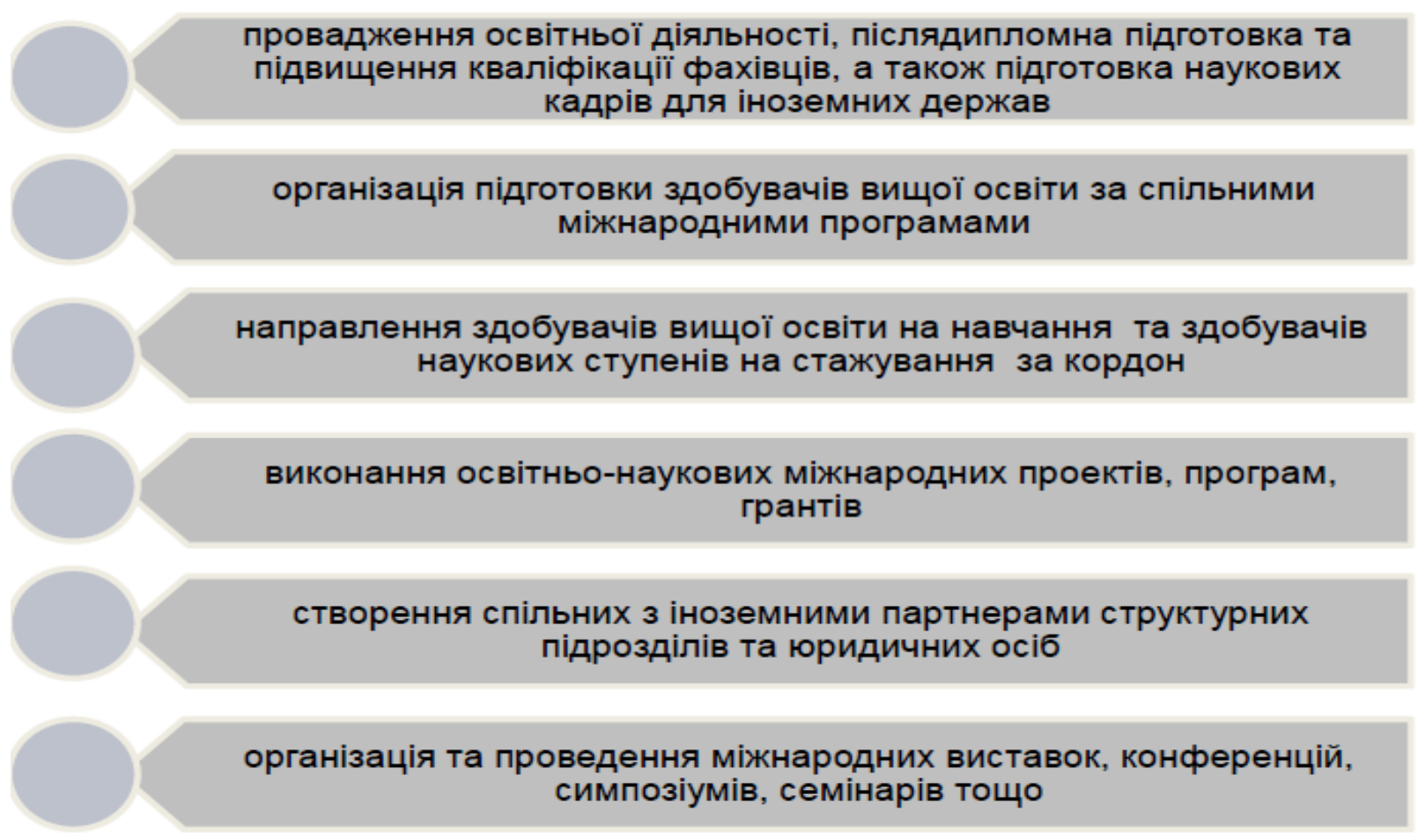

Рис. 3. Трансфер освітніх послуг

Джерело: систематизовано на підставі [10; 11; 12]

Зовнішньоекономічна діяльність університету здійснює значний вплив на процес інтернаціоналізації вищого навчального закладу. Фактично вона виступає внутрішнім механізмом реалізації процесу. Кошти, отримані університетом у результаті зовнішньоекономічної діяльності (рис.4), становлять важливий ресурс його інтернаціоналізації за усіма напрямами. Більш того, отриманий прибуток від експорту освітніх та інших послуг дозволить забезпечити потребу університету в імпорті освіти, що є важливим кількісним та якісним показником інтернаціоналізації освітнього процесу. 


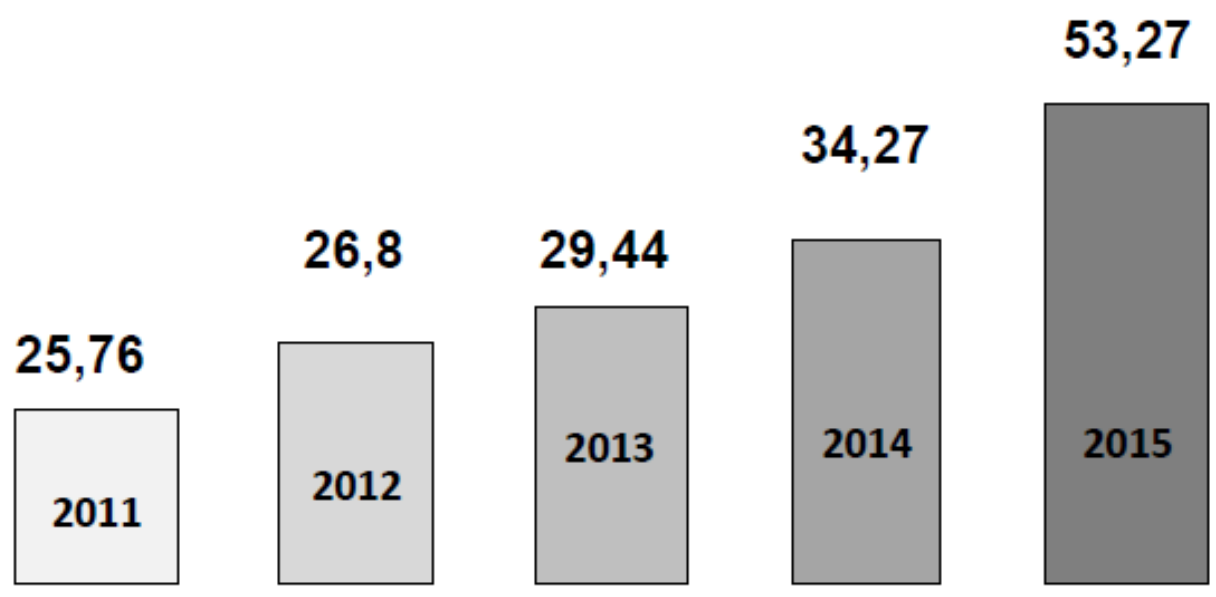

Рис. 4. Динаміка отримання коштів від зовнішньоекономічної діяльності КПІ ім. Ігоря Сікорського [13]

Висновки. Проведене у статті дослідження дозволяє зробити наступні висновки:

- інтернаціоналізація є процесом інтеграції міжнародних елементів в освітні, наукові та адміністративні функції ВН3, що забезпечує конкурентоздатність та зміцнення потенціалу вітчизняних університетів, інтеграцію української системи вищої освіти до європейського освітнього простору;

- зовнішньоекономічна діяльність як вид активності ВНЗ, знаходить прояв у кожному напрямі інтернаціоналізації університету, при цьому виступає важливим економічним ресурсом зазначеного процесу;

- надходження коштів від експорту освітніх та інших дозволених університету послуг здатне забезпечити потребу ВНЗ в імпорті освіти.

Наукова новизна статті полягає в удосконаленні методичного підходу до використання освітнього потенціалу вищого навчального закладу у складовій «зовнішньоекономічна діяльність університету» як ключового ресурсу, який, на відміну від існуючих підходів, здатен і надає можливість забезпечити підвищення рівня ефективності економічної складової діяльності ВНЗ на основі інтернаціоналізації освітніх закладів.

Практичне значення отримані результати мають для стратегічного планування міжнародної діяльності та поточного здійснення зовнішньоекономічної діяльності ВНЗ у частині ранжування видів науковоосвітніх послуг та додаткових дозволених університету сервісів.

У перспективі необхідним вбачається подальше дослідження проблеми зовнішньоекономічної діяльності університету вже не тільки в якості ресурсу інтернаціоналізації, але одночасно і як внутрішнього механізму реалізації зазначеного процесу. 


\section{Література:}

1. Згуровський М. 3. Болонський процес: головні принципи та шляхи структурного реформування вищої освіти України / М. З. Згуровський. - К.: НТУУ "КПІ", 2006. - 544 с.

2. Шишолін А. П. Міжнародні інноваційно-орієнтовані організації та їх діяльність / А. П. Шишолін, Я. Д. Мельник, С. В. Войтко // Міжнародна економіка: інтеграція науки та практики: збірн. наук. праць. - К., 2013. - Вип. 3. - 208-213 с.

3. Altbach P. G. Knowledge and education as international commodities: The collapse of the common good / P. G. Altbach. // International Higher Education. - 2002. - №28. - C. 2-5.

4. Altbach P. G. GATS Redux: The WTO and Higher Education Returns to Center Stage / P. G. Altbach. // International Higher Education. - 2004. - №37. - C. 5-7.

5. Шишолін А. П. Порівняльна характеристика ефективності національноінноваційної системи Китайської Народної Республіки та Республіки Білорусь / А. П. Шишолін, Я.Д. Мельник, С. В. Войтко // Міжнародне науково-технічне співробітництво: принципи, механізми, ефективність: матер. X (XXII) Міжнар. наук.-практ. конф. - К., 2014. - С. 82.

6. Згуровський М. 3. Розробка методики визначення рівня загроз сталому розвитку України / М. 3. Згуровський, О. А. Гавриш, С. В. Войтко // Економічний вісник НТУУ «КПІ» : збірник наукових праць. - 2011. - № 8. - С. 26-33

7. Altbach P. G. Tracking an Academic Revolution. A Report Prepared for the. UNESCO 2009 World Conference on Higher Education. / P. G. Altbach, L. Reisberg, E. Laura. Rotterdam: Sense, 2009. - 246 c.

8. Knight J. Internationalization: A Decade of Changes and Challenges // International Higher Education. - 2008. - №50. - P. 6-7.

9. Інтернаціоналізація повинна стати складовою вищої освіти: [виступ першого заступника Міністра освіти і науки Совсун I. на семінарі] - [Електронний ресурс] - Режим доступу: http://mon.gov.ua/usi-novivni/novini/2015/09/16/internaczionalizacziya-ukrayinskoyivishhoyi-osviti/.

10. Про зовнішньоекономічну діяльність: Закон України в редакції від 25.04.2008 р. № 959-XII [Електронний ресурс] // ВВР. - 1991. - №29. - ст.377. - Режим доступу: http://zakon.rada.gov. ua/cgi-bin/laws/main.cgi?nreg=959-12.

11. Про затвердження Положення про зовнішньоекономічну діяльність в Національному технічному університеті України «Київський політехнічний інститут»: Наказ НТУУ «КПІ» № 3-28 від 11.02.2015 р. [Електронний ресурс] - Режим доступу: http://kpi.ua/ru/search/google/\%D0\%BD\%D0\%B0\%D0\%BA\%D0\%B0\%D0\%B7\%203-28.

12. GENERAL AGREEMENT ON TRADE IN SERVICES [Електронний ресурс] Режим доступу: https://www.wto.org/english/docs_e/legal_e/26-gats.pdf.

13. Сидоренко С. І. Про підсумки міжнародної діяльності у 2015 році та завдання на 2016 рік: матеріали річного звіту [Електронний ресурс] / С. І. Сидоренко. - Режим доступу: http://icd.kpi.ua/documents/zvity/Zvit-2015_08-02-2016.pdf. 